\title{
Effect off host plant species on immature development and adult size of Neoleucinodes elegantalis (Guenée 1854) (Lepidoptera: Crambidae)
}

\author{
Wendel Teles Pontes ${ }^{1}$ (D) \& Reginaldo Barros ${ }^{2,3}$
}

(1) Universidade Federal de Pernambuco, Centro de Ciências Biológicas, Departamento de Zoologia, Cidade Universitaria 50670-420, Recife, Pernambuco, Brazil. E-mail: pontes.wendel@gmail.com

(2) Universidade Federal Rural de Pernambuco, Departamento de Agronomia, Av. Dom Manoel de Medeiros, Dois Irmãos 52171-900, Recife, Pernambuco, Brazil. E-mail: reginaldo.barros@ufrpe.br

(3) Universidade Federal Rural de Pernambuco, Departamento de Agronomia, Programa de PósGraduação em Entomologia Agrícola, Av. Dom Manoel de Medeiros, Dois Irmãos 52171-900, Recife, Pernambuco, Brazil.

Pontes W.T. \& Barros R. (2020) Effect off host plant species on immature development and adult size of Neoleucinodes elegantalis (Guenée 1854) (Lepidoptera: Crambidae). Pesquisa e Ensino em Ciências Exatas e da Natureza, 4: e1311. http://dx.doi.org/10.29215/pecen.v4i0.1311

Academic editor: Etielle Barroso de Andrade. Received: 13 November 2018. Accepted: 17 January 2020. Published: 31 January 2020.

Efeito de plantas hospedeiras sobre o desenvolvimento larval e tamanho do adulto em Neoleucinodes elegantalis (Guenée 1854) (Lepidoptera: Crambidae)

Resumo: Plantas hospedeiras afetam vários traços de insetos. As causas dessas mudanças são relacionadas à adequação das plantas, em relação a seus caracteres físicos e químicos e suas consequências fisiológicas nos insetos. Muitos dos fatores que afetam o desempenho dos insetos são caracteres ecológicos e nutricionais de plantas. Durante o estágio larval, a variação no consumo de alimentos reverbera na morfologia e desempenho geral do adulto, especialmente em insetos holometábolos. Um balanço entre os traços da história de vida frente a diferentes hospedeiros é comum, pois mudanças no tempo de desenvolvimento larval influenciam no tamanho. Para investigar o papel da planta hospedeira no estágio larval e como ela reflete sobre o tamanho adulto, examinamos a história de vida imatura da broca Neoleucinodes elegantalis (Lepidoptera: Crambidae) em quatro plantas hospedeiras. O desenvolvimento larval e a taxa de crescimento são afetados pela planta hospedeira, mas o tamanho da pupa é igual para todos os hospedeiros. A taxa de crescimento das fêmeas é maior que a dos machos em todos os hospedeiros, e nos hospedeiros foi maior em Solanum gilo do que Lycopersicum esculentum, mas igual em insetos crescidos em $S$. melongena e Capsicum annuum. Fatores que afetam essas diferenças foram discutidos.

Palavras chave: Desenvolvimento larval, broca do tomate, Solanum, Capsicum, Lycopersicum.

Abstract: Host plants affects several traits of insects. The causes of these changes relay on suitability of plants, regarding its physical and chemical characters and its physiological consequences on insects. Many of these factors that affects insect performance are ecological and nutritional plant characters. During larval stage, variation in food consumption reverberates on adult's morphology and overall performance, especially in holometabolous insects. A trade-off among life history traits in face of different hosts is common, as changes in larval development time influencing the final size. To investigate the role of host plant on the larval stage and how it reflects on adult size, we examined the immature life history patterns of the tomato fruit borer Neoleucinodes elegantalis (Lepidoptera: Crambidae) in four commercial host plants. We found that larval development and growth rate is affected by the host plant, but the pupal size is equal for all hosts. Female growth rate is higher than males in all host. Overall growth rate was higher in Solanum gilo than Lycopersicum esculentum, but equal to insects came from S. melongena and Capsicum annuum. Factors affecting these differences were discussed.

Key words: Larval development, tomato fruit borer, Solanum, Capsicum, Lycopersicum. 


\section{Introduction}

Variation of insect performance in different hosts is a well-known phenomenon (Bernays \& Chapman 1994; Tikkanen et al. 2000; Schoonhoven et al. 2005). Host plants may affect development time, body size, longevity, fecundity (Barros et al. 2010), behavior (Shelly \& Villalobos 2004), delay in mating and maturation of eggs (Gotthard et al. 2005; Naseri et al. 2009; Maeno \& Tanaka 2011). The causes of these changes relay mainly on suitability of hosts and its physiological consequences on insects. Many factors that directly affects insect performance are digestion rate (Xue et al. 2010), presence of chemical defenses (Mithöfer \& Boland 2012), plant nutritional profile (Awmack \& Leather 2002; Chandler et al. 2008) and in some extent ecological factors, as the pressure of natural enemies (Berger \& Gotthard 2008).

During larval stage, variation in food consumption reverberates on adult's morphology and overall performance, especially in holometabolous insects. For example, reduction of larval food in Speyeria mormoni (Boisduval, 1869) directly affects adult body size, sexual size dimorphism and fecundity (Boggs \& Freeman 2005). Variations in protein and carbohydrate contents of food during larval stage affects the degree of resources that will be allocated on somatic and reproductive tissues in adults, with consequences on reproduction (Colasurdo et al. 2009). Variation in nitrogen content of plants also affects consumption rate and reflects directly on development of insects (Mattson 1980).

A trade-off among life history traits in face of different hosts is common. Increasing the potential of reproduction may be constrained by reduction in adult longevity (Paukku \& Kotiaho 2008; Sarfraz et al. 2010). These trade-offs are observed mainly on traits as development time and body size. It is commonly accepted that a long development time reflects on larger adult size, although this correlation may be affected by factors as growth rate (Nylin \& Gotthard 1998; Davidowitz et al. 2005) and decision to pupate (Shafiei et al. 2001). Thus, changes in suitability of hosts resulting in variability of host-dependent development time and adult size suggest that insect population may be directly affected by distribution and suitability of these hosts.

To investigate the role of host plant on the larval stage and how it reflects on adult size, we examined the immature life history patterns of the tomato fruit borer Neoleucinodes elegantalis (Guenée) (Lepidoptera: Crambidae), a well-known pest of commercial Solanaceae in neotropical region. The life history of $N$. elegantalis has been assessed using tomato (Solanum lycopersicum Linnaeus) and scarlet eggplant (Solanum melongena Linnaeus) as host plant (Marcano 1991a,b). Although N. elegantalis is found in commercial capsicum (Capsicum annuum Linnaeus) (Valle et al. 2003) and in gilo fruits (Solanum gilo Linnaeus) (Picanço et al. 1997), and that the host plant can both reproductive compatibility (Díaz-Montilla et al. 2018) and morphology of reproductive organs (Noboa et al. 2017), its larval performance on these hosts is poor understood. Fruit damage of $N$. elegantalis has been registered in several Solanaceae species (Toledo 1948; Diaz \& Solis 2007), but mostly researches focuses in this species grown in tomato (Picanço et al. 1998; Blackmer et al. 2001; Jordão \& Nakano 2000; Paula et al. 2004; Picanço et al. 2007).

We evaluated the effects of the hosts on the development time, growth rate and the correlation between pupal size an adult size of $N$. elegantalis reared in four commercially produced Solanaceae species (S. melongena, S. gilo, $C$. annuum and $S$. lycopersicum). We also assessed if the growth rate is affected by sexual differences.

\section{Material and Methods}

The insects used in this experiment came from a laboratory colony founded in 2010. Newly hatched larvae were placed on fruits of eggplant, tomato, scarlet eggplant and capsicum. Fruits were obtained from commercial crops and the experiment was carried out in an acclimatized chamber were the temperature was constant at $25 \pm 1^{\circ} \mathrm{C}$ and relative humidity of 70 $\pm 3 \%$, with photophase of 12 hours in light and 12 hours in darkness. 
A total of ten larvae were used per $L$. esculentum and $S$. gilo. Once $C$. annuum is twice larger in size than $L$. esculentum and $S$. gilo fruits, twenty larvae were transferred in each fruit. $S$. melongena is the larger one, both in size and volume, and thirty larvae were transferred from the laboratory colony and placed in each fruit. After transference, L. esculentum and $S$. gilo fruits were kept isolated in plastic pots $(300 \mathrm{~mL})$ whose lids are perforated for gas exchange. $C$. annuum and $S$. melongena fruits were isolated in larger plastic pots $(2 \mathrm{~L})$. Fruits were inspected daily and last-instar larvae found in a period minor or equal to ten days after transference were considered to be from field infestation and discarded for the analysis.

Some fruits of $S$. melongena and $C$. annuum did not sustained integrity before the complete larval development. These fruits were gently opened with a knife and all larvae found in intermediate developmental stage were kept with a fine brush and transferred to a new fruit. A punch was done on the surface of each fruit, as larger as the size of the larvae to be transferred, in the way to give access to the inside. After complete entrance of larvae, each punch was sealed with sticky paper to minimize fungal and bacterial contamination. This procedure has been performed only in degenerating fruits, in a way that larvae from degenerating fruits were transferred only once.

In the way to measure growth based on food intake, larvae in a pre-pupal stage - soon after leave fruits - were heighted in a digital balance Md Q500L21OC Quimis ${ }^{\circledast}$, SP, Brazil, with accuracy of $0.1 \mathrm{mg}$, and individualized in plastic vials until adult emergence. To access a possible cost of metamorphosis at pupation and influence of host on this cost, we measured the initial adult size soon after emergence $(<24 \mathrm{~h})$ after elimination of meconium. Day of pupation, pupal duration, adult height and sex were registered. The sex of each newly emerged moth was determined by comparing abdomen tip (Pontes et al. 2013).

To measure growth rate between hosts, we used data registered until pupal stage before sex determination, including those insects that died before emergence. To calculate the growth rate between sexes, we used all insects that reached adulthood. To calculate the growth rate from each host, we used the formula: Growth rate $=[\ln ($ Pupal weight $)-\ln$ (hatchling weight)]/time of larval development (Gotthard et al. 1994). The hatchling weight was constant $(0.19 \mathrm{mg})$, estimated on the weight of 10 samples of 15 newly hatched individuals from the laboratory colony.

Data were checked for normality by Shapiro-Wilk Test. For count data (larval duration, pupal duration), we used generalized linear models (GLM) with Poisson error distribution and link log. Corrections for overdispersion were done when necessary by refitting the model with quasi-poisson errors. For non-normal data, a Kruskal-Wallis test was performed, considering the level of significance set below 0.05. For normally distributed data, a one-way ANOVA were performed with different hosts as categorical variable. All tests were performed in $\mathrm{R}$ program version 2.10.0, using packages pgirmess and nlme ( $\mathrm{R}$ Development Core Team 2009).

\section{Results}

Larval time was longer in $L$. esculentum compared to $S$. gilo (Kruskal-Wallis $\chi^{2}=35.60$, $\mathrm{df}=3, \mathrm{p}<0.05)$ (Figure 1), however, both were similar to those of $S$. melongena and $C$. annuum. Pupal duration is not related to pupal weight in all hosts (GLM with Poisson error $\chi^{2}=0.10, \mathrm{df}=$ $1, \mathrm{p}=0.751)$.

Pupal weight, pre-pupal weight and adult weight are correlated, for all hosts $\left(\mathrm{F}_{1.158}=\right.$ 63.27, $\mathrm{p}=0.024$ ) (Figure 2). Adult weight is not related with larval developmental time (GLM Poisson error $\chi^{2}=0.0005, \mathrm{df}=1, \mathrm{p}=0.98$ ), nor with the hosts (GLM Poisson error $\chi^{2}=0.33, \mathrm{df}=3$, $\mathrm{p}=0.95)$.

The hosts affected growth rate of $N$. elegantalis (Kruskal-Wallis $\chi^{2}=17.30, \mathrm{df}=3, \mathrm{p}<$ 0.001) (Figure 3). Insects reared in $S$. gilo fruits differed from those reared in $L$. esculentum fruits in growth rate $(3.73 \mathrm{mg} /$ day and $3.59 \mathrm{mg} /$ day, respectively) $(\mathrm{p}<0.05)$, however both were similar to insects reared in $S$. melongena ( $3.65 \mathrm{mg} /$ day) and $C$. annuum. (3.62 mg/day). Female 
growth rate is significantly higher than male growth rate in all hosts, where females grew 3.82 $\mathrm{mg} /$ day and males grew $3.60 \mathrm{mg} /$ day $\left(\mathrm{F}_{1.178}=55.07, \mathrm{p}<0.001\right)$ (Figure 4).

The method to replace larvae from rotting fruits to intact ones showed to be satisfactory in the way to enable the fully larval development in laboratory conditions. Data of mortality to those insects from replaced fruits was missing because was impossible to recover the same number of larvae initially transferred to fruits. However, those recovered reached adulthood and were similar to adults from intact fruits.

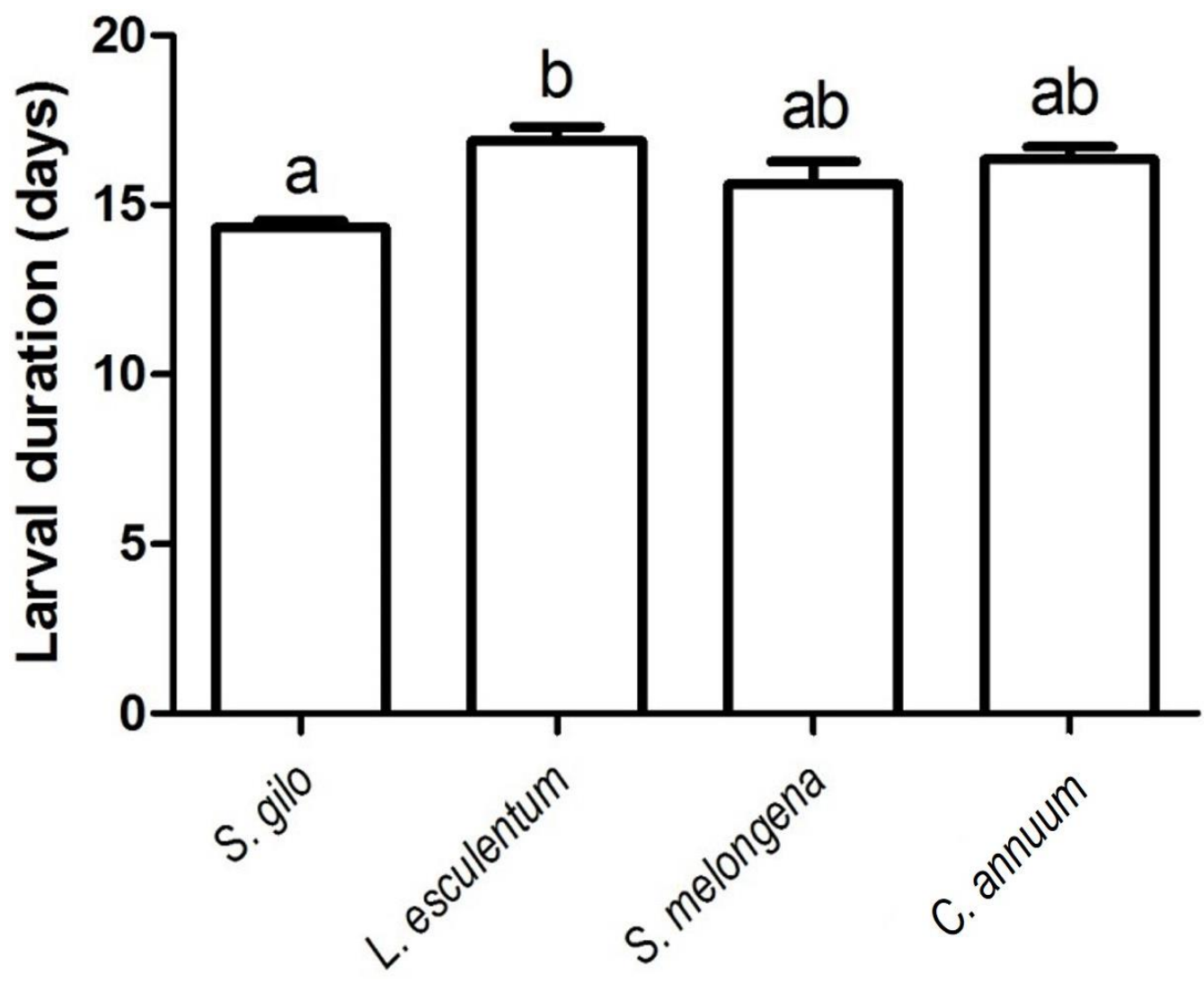

Figure 1. Development time of $N$. elegantalis reared in four host species.

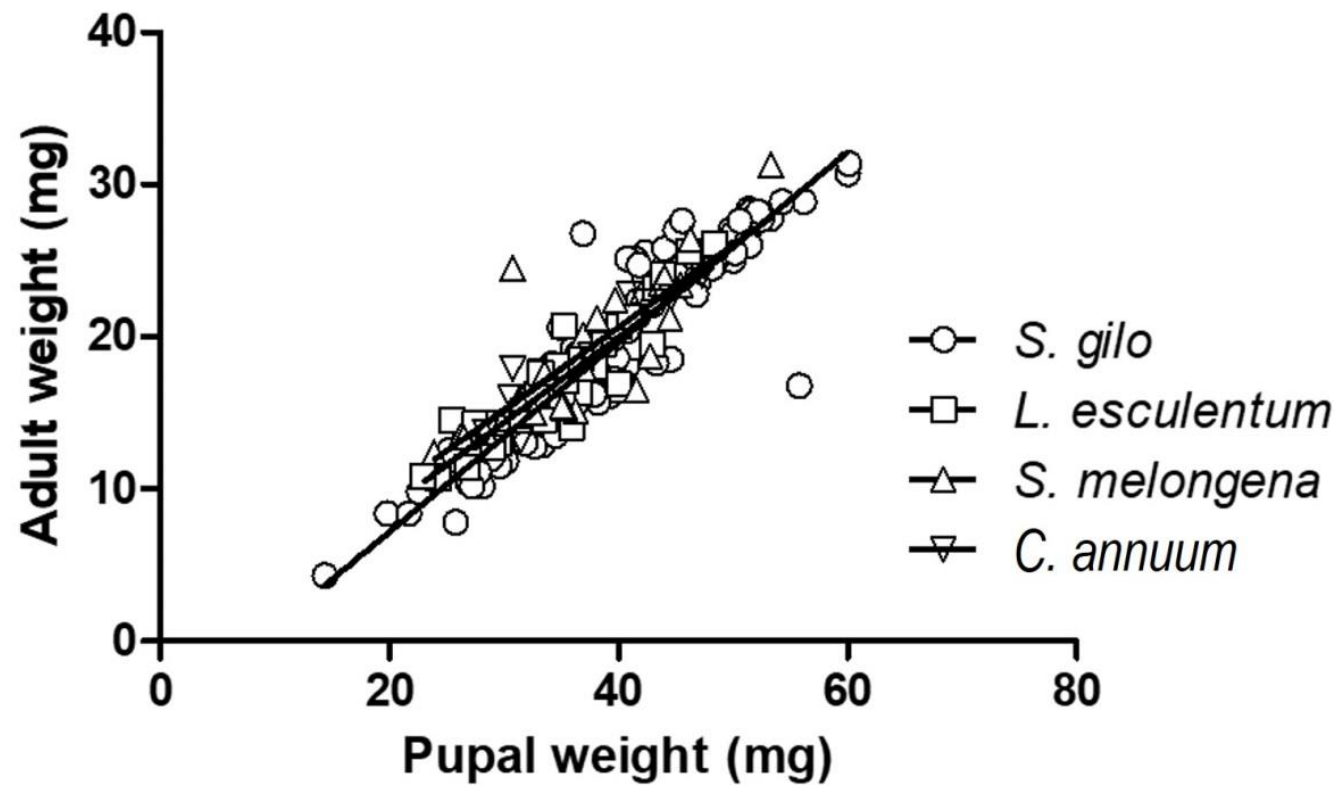

Figure 2. Relation of adult weight and pupal weight for all hosts. 


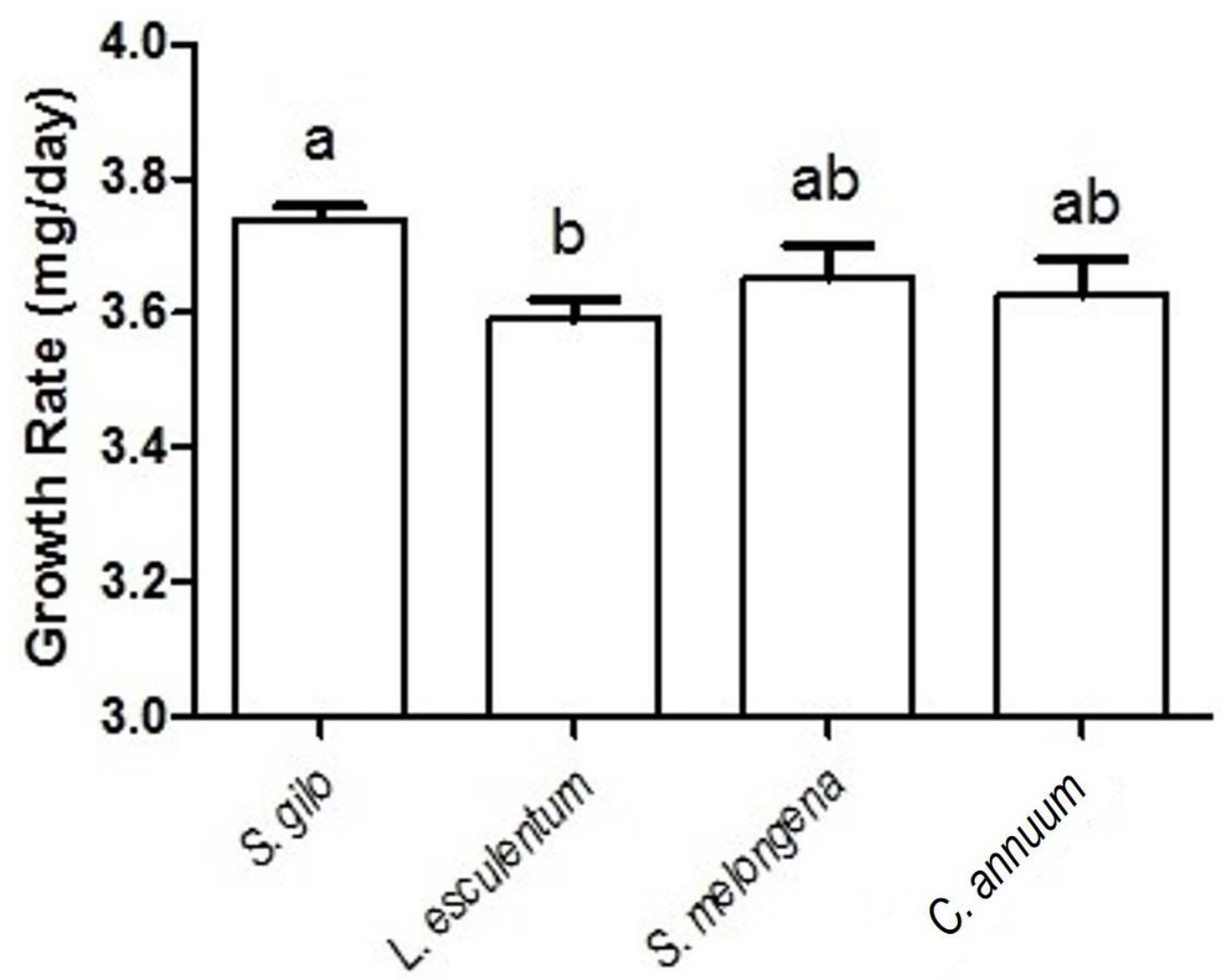

Figure 3. Growth rate of $N$. elegantalis reared in four hosts.

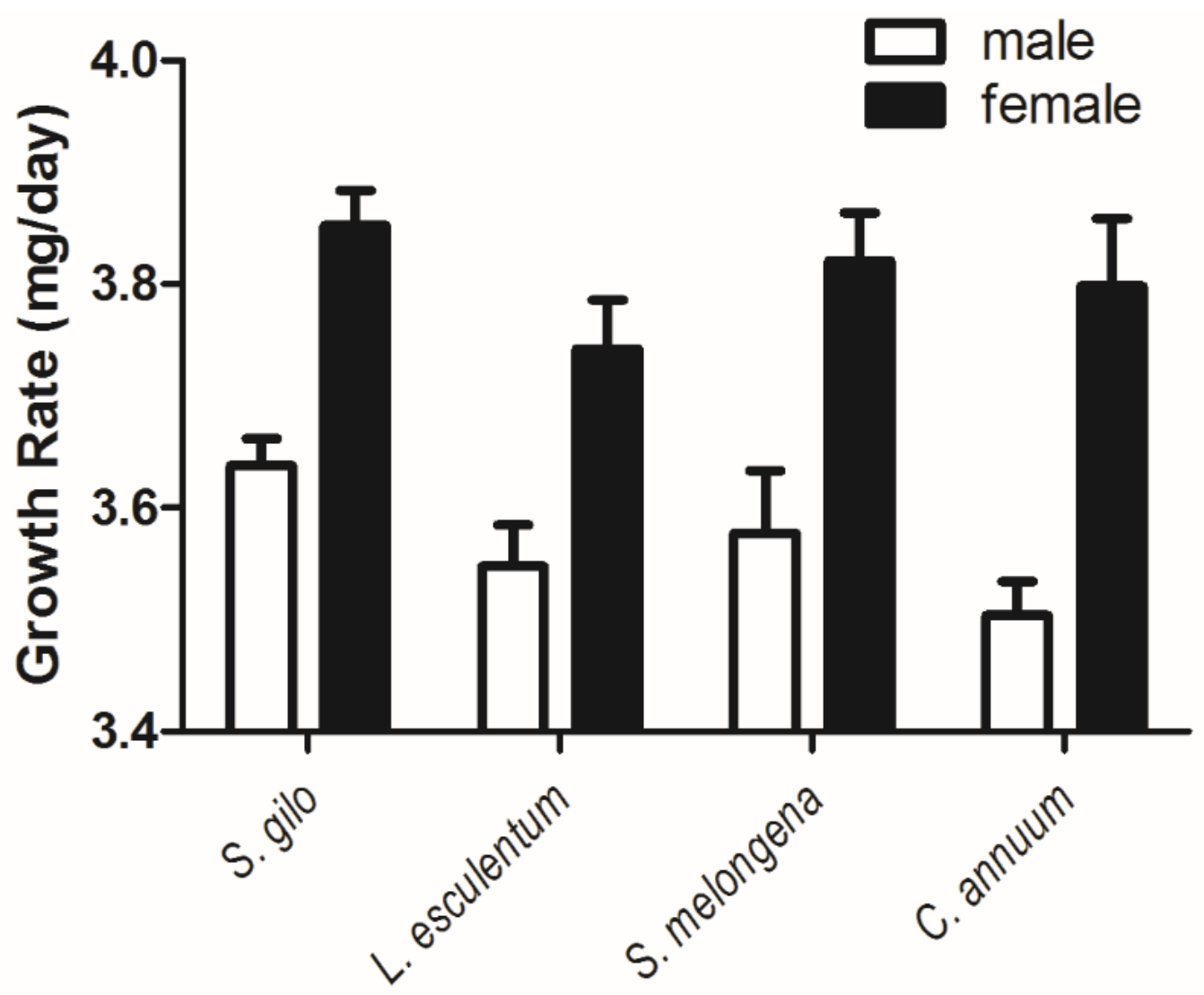

Figure 4. Growth rate of males and females in four hosts, where females are growing faster than males $(\mathrm{p}<$ $0.001)$. 


\section{Discussion}

Similarities in weight gain and duration of larval stage in different hosts indicates that $N$. elegantalis is adapted to feed and develop in the Solanaceae hosts tested. This evidence corroborates previous observation that several wild and commercially important species of Solanaceae are natural hosts of many species of the genera Neoleucinodes, including $N$. elegantalis (Diaz \& Solis 2007). Although larvae reared in S. gilo grow faster than others, the results of pupal size show that larvae reach adulthood at the same size irrespective of the host plant.

Correlation between pupal duration and larval development time is found in many insects (Shahout et al. 2011; Ansari et al. 2012) and is related with host plant quality (Roy \& Barik 2013). Although evidences suggest that more suitable host is those on which larval development time is the shortest and pupal weight is the heaviest (Penz \& Araújo 1990; Wu et al. 2011), there is conflicting results concerning this relation. Larval duration is the same for Plutella xylostella (Linnaeus) reared in both hosts and non-hosts plants, although pupal duration is significantly longer on non-hosts ones (Sarfraz et al. 2010). However, larval duration and pupation are the shortest on the best host compared to minor suitable one, in Spodoptera litura (J.E. Smith) (Shahout et al. 2011).

Larval development time is not associated with heavier or lighter pupae in $N$. elegantalis. This means that the time spent during larval stage not implies on increasing in feeding duration, or ingestion efficiency. The longest time spent in the host $L$. esculentum compared to $S$. gilo resulted in insects with the same size as those feed in $S$. melongena and $C$. annuum.

There are some hypotheses to explain the differences found among L. esculentum and S. gilo. First, the water content of fruits may change the efficiency of digested food, reducing the daily weight gain and thus prolonging larval duration (Timmins et al. 1988). Water content of tomato fruits are around 95\% (Mitchel et al. 1991) while water content of $S$. gilo is around $89 \%$ (Chinedu et al. 2011). This may be the cause that larvae reared on $S$. gilo grew faster than those reared in L. esculentum, but both reached the same size at pupation. Second, changes in feeding bout length and frequency during larval stage can prolong larval development time (Timmins et al. 1988; Usher et al. 1988). Feeding bout is affected mainly by presence of chemical compounds that can reduce feeding stimulus (Glendinning \& Slansky 1995).

Males and females grew differently in all hosts, where females became larger than males during the same development time. Energetic demand of females is usually higher than males because oogenesis requires more energy and nutrients than spermatogenesis (Slansky \& Scriber 1985; Hayward \& Gillooly 2011). Both males and females are subject to the same conditions when developing in host plants, however, females grew more than males, suggesting that ingestion rate or conversion of ingested food in females are more efficient (Telang et al. 2001). As reproductive success of females is size-dependent (Honek 1993), selection to increase female fecundity by increasing female size may act on female's ability to feed and convert food more efficiently in energy reserves for oogenesis and formation of reproductive organs.

In resume, we found that $L$. esculentum, $C$. annuum, $S$. gilo and $S$. melongena affect $N$. elegantalis development time, but did not affect the size of adults. This suggests that differences among the hosts impose conditions that delay or increase development time, but not in a way that can compromise size and morphology of adults. Females grew more than males in all hosts.

\section{Acknowledgments}

The authors are grateful to the anonymous reviewers for critically reviewing the manuscript. WTP and RB would like to thanks CAPES and FACEPE for the funding support of this work, grants AUX-PE Parceria 772/2011. RB thanks CNPq for scholarship.

\section{References}


Ansari M.S., Hasan F. \& Ahmad N. (2012) Influence of various host plants on the consumption and utilization of food by Pieris brassicae (Linn.). Bulletin of Entomological Research, 102: 231-237. https://doi.org/10.1017/S000748531100054X

Awmack C.S. \& Leather S.R. (2002) Host plant quality and fecundity in herbivorous insects. Annual Review of Entomology, 47: 817-844. https://doi.org/10.1146/annurev.ento.47.091201.145300

Barros E.M., Torres J.B., Ruberson J.R. \& Oliveira M.D. (2010) Development of Spodoptera frugiperda on different hosts and damage to reproductive structures in cotton. Entomologia Experimentalis et Applicata, 137: 237-245. https://doi.org/10.1111/j.1570-7458.2010.01058.x

Berger D. \& Gotthard K. (2008) Time-stress, predation risk and diurnal-nocturnal foraging tradeoffs in larval prey. Behavioural Ecology and Sociobiology, 62: 1655-1663. https://doi.org/10.1007/s00265-008-0594-4

Bernays E.A. \& Chapman R.F. (1994) Host-plant selection by phytophagous insects. New York: Chapman \& Hall. 312 p.

Blackmer J., Eiras A. \& Souza C. (2001) Oviposition preference of Neoleucinodes elegantalis (Guenée) (Lepidoptera: Crambidae) and rates of parasitism by Trichogramma pretiosum Riley (Hymenoptera: Trichogrammatidae) on Lycopersicon esculentum in São José de Ubá, RJ, Brazil. Neotropical Entomology, 30: 89-95. http://dx.doi.org/10.1590/S1519-566X2001000100014

Boggs C.L. \& Freeman K.D. (2005) Larval food limitation in butterflies: effects on adult resource allocation and fitness. Oecologia, 144: 353-361. https://doi.org/10.1007/s00442-005-0076-6

Chandler S.M., Wilkinson T.L. \& Douglas A.E. (2008) Impact of plant nutrients on the relationship between an herbivorous insect and its symbiotic bacteria. Proocedings of the Royal Society of London B, 275: 565-570. https://doi.org/10.1098/rspb.2007.1478

Chinedu S.N., Olasumbo A.C., Eboji O.K., Emiloju O.C., Arinola O.K. \& Dania D.I. (2011) Proximate and phytochemical analysis of Solanum aethiopicum L. and Solanum macrocarpon L. fruits. Research Journal of Chemical Sciences, 1: 63-71.

Colasurdo N., Gélinas Y. \& Despland E. (2009) Larval nutrition affects life history traits in a capital breeding moth. The Journal of Experimental Biology, 212: 1794-1800. https://doi.org/10.1242/jeb.027417

Davidowitz G., Roff D.A. \& Nijhout H.F. (2005) A physiological perspective on the response of body size and development time to simultaneous directional selection. Integrative \& Comparative Biology, 45: 525-531. https://doi.org/10.1093/icb/45.3.525

Diaz A.E. \& Solis M.A. (2007) A new species and species distribution records of Neoleucinodes elegantalis (Lepidoptera: Crambidae: Spilomelinae) from Colombia feeding on Solanum sp. Proceeding of the Entomological Society of Washington, 109: 897-908.

Diaz-Montilla A.E., Baena-Bejarano N., Montoya-Lerma J. \& Saldamando-Benjumea C.I. (2018) Reproductive incompatibility and fitness components in Neoleucinodes elegantalis races (Lepidoptera, Crambidae) from three Solanaceae hosts. Caldasia, 40: 199-215. http://dx.doi.org/10.15446/caldasia.v40n2.67241

Glendinning J.I. \& Slansky Jr. F. (1995) Consumption of a toxic food by caterpillars increases with dietary exposure: support for a role of induced detoxification enzymes. Journal of Comparative Physiology A, 176: 337-345. https://doi.org/10.1007/BF00219059

Gotthard K., Nylin S. \& Wiklund C. (1994) Adaptative variation in growth rate: life history costs and consequences in the speckled wood butterfly, Pararge aegeria. Oecologia, 99: 281-289. https://doi.org/10.1007/BF00627740

Gotthard K., Margraf N., Rasmann S. \& Rahier M. (2005) The evolution of larval foraging behavior in response to host plant variation in a leaf beetle. Oikos, 109: 503-512.

https://doi.org/10.1111/j.0030-1299.2005.14074.x

Hayward A. \& Gillooly J.F. (2011) The cost of sex: quantifying energetic investment in gamete production by males and females. PLOS ONE, 6(1): e16557.

https://doi.org/10.1371/journal.pone.0016557 
Honek A. (1993) Intraspecific variation in body size and fecundity in insects - a general relationship. Oikos, 66: 483-492. https://doi.org/10.2307/3544943

Jordao A. \& Nakano O. (2000) Controle de lagartas dos frutos do tomateiro pelo ensacamento de pencas. Anais da Sociedade Entomologica do Brasil, 29: 773-782.

http://dx.doi.org/10.1590/S0301-80592000000400018

Maeno K. \& Tanaka S. (2011) Phase-specific responses to different qualities of food in the desert locust, Schistocerca gregaria: developmental, morphological and reproductive characteristics. Journal of Insect Physiology, 57: 514-520. https://doi.org/10.1016/j.jinsphys.2011.02.004

Marcano R. (1991a) Ciclo biológico del perforador del fruto del tomate Neoleucinodes elegantalis (Guenée) (Lepidoptera: Pyralidae), usando berenjena (Solanum melongena) como alimento. Boletin de Entomologia Venesolana, 6: 135-141.

Marcano R. (1991b) Estudio de la biologia y algunos aspectos del comportamiento del peforador del fruto del tomate Neoleucinodes elegantalis (Lepidoptera: Pyralidae) en tomate. Agronomia Tropical, 41: 27-264.

Mattson W.J. (1980) Herbivory in relation to plant nitrogen content. Annual Review of Ecology Systematics, 11: 119-161. https://doi.org/10.1146/annurev.es.11.110180.001003

Mitchell J.P., Shennan C., Grattan S.R. \& May D.M. (1991) Tomato fruit yields and quality under water deficit and salinity. Journal of the American Society for Horticultural Science, 116: 215-221. https://doi.org/10.21273/JASHS.116.2.215

Mithöfer A. \& Boland W. (2012) Plant defense against herbivores: chemical aspects. Annual Review of Plant Biology, 63: 431-450. https://doi.org/10.1146/annurev-arplant-042110-103854

Naseri B., Fathipour Y., Moharramipour S. \& Hosseinninaveh V. (2009) Comparative life history and fecundity of Helicoverpa armigera (Hubner) (Lepidoptera: Noctuidae) on different soybean varieties. Entomological Science, 12: 147-154.

https://doi.org/10.1111/j.1479-8298.2009.00310.x

Noboa M., Viera W., Díaz A., Vásquez W. \& Ron L. (2017) Genitalic differentiations in Neoleucinodes elegantalis (Guenée) (Lepidoptera: Crambidae) associated with Solanaceae crops in Ecuador. Insects, 8: E91. https://doi.org/0.3390/insects8030091

Nylin S. \& Gotthard K. (1998) Plasticity in life-history traits. Annual Review of Entomology, 43: 63-83. https://doi.org/10.1146/annurev.ento.43.1.63

Paukku S. \& Kotiaho J.S. (2008) Female oviposition decisions and their impact on progeny lifehistory traits. Journal of Insect Behavior, 21: 505-520. https://doi.org/10.1007/s10905-008-9146$\mathrm{z}$

Paula S.V., Picanço M.C., Oliveira I.R. \& Gusmão M.R. (2004) Controle de broqueadores de frutos de tomateiro com uso de faixas de culturas circundantes. Bioscience Journal, 20: 33-39.

Penz C.M. \& Araújo A.M. (1990) Interaction between Papilio hectorides (Papilionidae) and four host plants (Piperaceae, Rutaceae) in a southern Brazilian population. Journal of Research on the Lepidoptera, 29: 161-171.

Picanço M.C., Leite G.L.D., Guedes R.N.C. \& Silva E.A. (1998) Yield loss in trellised tomato affected by insecticidal sprays and plant spacing. Crop Protection, 17: 447-452. https://doi.org/10.1016/S0261-2194(98)00040-4

Picanço M.C., Bacci L., Crespo A.L.B., Miranda M.M.M. \& Martins J.C. (2007) Effect of integrated pest management practices on tomato Lycopersicon esculentum, production and preservation of natural enemies of pests. Agricultural and Forest Entomology, 9: 201-212. https://doi.org/10.1111/j.1461-9563.2007.00346.x

Picanço M.C., Casali V.W.D., Leite G.L.D. \& Oliveira I.R. (1997) Lepidópteros associados ao jiloeiro (Solanum gilo Raddi). Horticultura Brasileira, 15: 112-114.

Pontes W.J.T., Cunha E.G., Araújo H.D., Barros R. \& Lima E. (2013) Virgin and recently mated males are equally able to achieve new matings in Neoleucinodes elegantalis. Physiological Entomology, 38: 313-317. https://doi.org/10.1111/phen.12036

R Development Core Team (2009). R: A language and environment for statistical computing. R Foundation for Statistical Computing, Vienna, Austria. ISBN 3-900051-07-0, URL http://www.R-project.org. 
Roy N. \& Barik A. (2013) Influence of four host-plants on feeding growth and reproduction of Diacrisia casignetum (Lepidoptera: Arctiidae). Entomological Science, 16: 112-118. https://doi.org/10.1111/j.1479-8298.2012.00546.x

Sarfraz R.M., Dosdall L.M. \& Keddie B.A. (2010) Performance of the specialist herbivore Plutella xylostella (Lepidoptera: Plutellidade) on Brassicaceae and non-Brassicaceae species. The Canadian Entomologist, 142: 24-35. https://doi.org/10.4039/n09-053

Schoonhoven L., van Loon J. \& Dicke M. (2005) Insect-Plant Biology. $2^{\circ}$ edition. Oxford: University Press. $421 \mathrm{p}$.

Shafiei M., Moczek A.P. \& Nijhout H.F. (2001) Food availability controls the onset of metamorphosis in the dung beetle Onthophagus Taurus (Coleoptera: Scarabaeidae). Physiological Entomology, 26: 173-180. https://doi.org/10.1046/j.1365-3032.2001.00231.x

Shahout H.A., Xu J.X., Yao X.M. \& Jia Q.D. (2011) Influence and mechanism of different host plants on the growth, development and fecundity of reproductive system of common cutworm Spodoptera litura (Fabricius) (Lepidoptera: Noctuidae). Asian Journal of Agricultural Science, 3: 291-300.

Shelly T.E. \& Villalobos E.M. (2004) Host plant influence on the mating success of male Mediterranean fruit flies: variable effects within and between individual plants. Animal Behaviour, 68: 417-426. https://doi.org/10.1016/j.anbehav.2003.08.029

Slansky F.J. \& Scriber J.M. (1985) Food consumption and utilization (p. 87-163). In: Kerkut G.A. \& Gilbert L.I. (Eds). Comprehensive Insect Physiology, Biochemistry and Pharmacology. Oxford: Pergamon Press. 565 p.

Telang A., Booton V., Chapman R.F. \& Wheeler D.E. (2001) How female caterpillars accumulate their nutrient reserves. Journal of Insect Physiology, 47: 1055-1064. https://doi.org/10.1016/s0022-1910(01)00085-3

Tikkanen O.-P., Niemelä P. \& Keränen J. (2000) Growth and development of a generalist insect herbivore, Operophtera brumata, on original and alternative host plants. Oecologia, 122: 529536. https://doi.org/10.1007/s004420050976

Timmins W.A., Bellward K., Stamp A.J. \& Reynolds S.E. (1988) Food intake, conversion efficiency, and feeding behavior of tobacco hornworm caterpillars given artificial diet of varying nutrient and water content. Physiological Entomology, 13: 303-314. https://doi.org/10.1111/j.1365-3032.1988.tb00482.x

Toledo A.A. (1948) Contribuição para o estudo da Leucinodes elegantalis Guen., praga do tomate. Biológico, 5: 103-108.

Usher B.E., Bernays E.A. \& Barbehenn R.V. (1988) Antifeedant tests with larvae of Pseudaletia unipuncta: variability of behavioral response. Entomologia Experimentalis et Applicata, 48: 203-212. https://doi.org/10.1007/BF00376399

Valle P.M., Cermeli M., Godoy F. \& Salas B. (2003) Lista de insectos relacionados a las solanáceas ubicados en el museo de insectos de interes agrícola del CENIAP-INIA. Entomotropica, 18: 193-209.

Wu B., Shen K., An K., Huang J. \& Zhang R. (2011) Effect of larval density and host species on pre imaginal development of Bartrocera tau (Diptera: Tephritidae). Journal of Economic Entomology, 104: 1840-1850. https://doi.org/10.1603/ec11154

Xue M., Pang Y.H., Wang H.T., Li Q.L. \& Liu T.X. (2010) Effects of four host plants on biology and food utilization of the cutworm Spodoptera litura. Journal of Insect Science, 10: 22. https://doi.org/10.1673/031.010.2201 